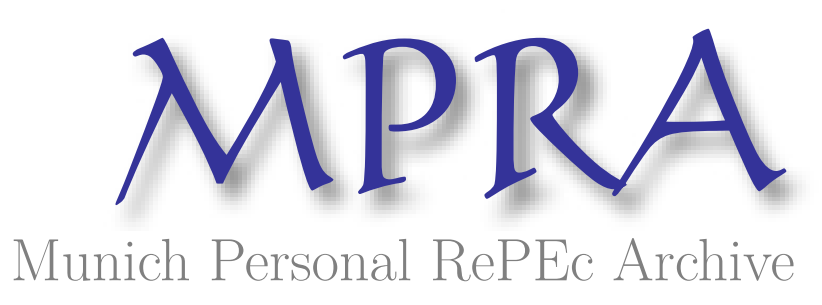

\title{
Real Options: Applications in Public Economics
}

Lawrence, Craig and Thomas, Mathew

30 June 2008

Online at https://mpra.ub.uni-muenchen.de/11915/

MPRA Paper No. 11915, posted 04 Dec 2008 04:01 UTC 


\title{
REAL OPTIONS: APPLICATIONS IN PUBLIC ECONOMICS
}

\author{
Mathew Thomas \\ Project Manager - Economic Advisory \\ Queensland Department of Tourism, \\ Regional Development and Industry \\ Brisbane, Australia \\ Phone: +61-7-3222-2966 \\ Email: mathew.thomas AT dtrdi.qld.gov.au
}

and

Craig Lawrence

Senior Economist

Connell Wagner Pty Ltd

Brisbane, Australia

Phone: +61-411-808-086

Email: lawrencecr AT conwag.com

\section{Disclaimer:}

The views expressed in this paper are solely those of the authors and do not reflect or represent the views of their respective employers. 


\title{
REAL OPTIONS: APPLICATIONS IN PUBLIC ECONOMICS
}

\begin{abstract}
This paper illustrates the use of real options principles to value prototypical resource and industry investment projects. It captures important competitive/strategic dimensions in a step-by-step analysis of investment decisions (options) under uncertainty. It compares and contrasts static discounted cash flow analysis (DCF) with real options analysis using three case studies. The initial example values a resource extraction process using static DCF and then compares the project valuation when future information is valued and acted upon. The second example considers a coal development and uses the binomial valuation approach to capture the option value associated with having the right but not the obligation to exit the development. It contrasts this valuation approach against static DCF and highlights that future royalty payments could be underestimated if based on the standard DCF valuation. The third example analyses the impact of providing a subsidy for hybrid vehicle production to accelerate potential uncertain environmental benefits. Lastly, the suitability of the standard financial and economic evaluation tools used by treasury agencies is considered when projects contain real options.
\end{abstract}

Key words: financial economics, investment decisions, public economics, externalities, subsidies, project evaluation

JEL Classification: G10, G11, H10, H23, H43 


\section{REAL OPTIONS: APPLICATIONS IN PUBLIC ECONOMICS}

\section{Introduction}

"Real option theory ... presumes that decision making is sequential and that decision makers may benefit from choosing options that seem sub optimal today but which increase flexibility at later times, leading to better decision making when more is known about the project." (HM Treasury (2003), p104)

Real option analysis is focused on describing uncertainty and, in particular, managerial flexibility inherent in many investment decisions. It takes on particular importance in uncertain and highly competitive global environments where investment decisions are frequently revised over time in response to unexpected market developments. Real options analysis gives the decision maker an opportunity but not the obligation to take future courses of action in relation to a project. Such options typically include the possibility to delay, expand, contract, or liquidate the project.

The availability of these real options creates inherent value, which makes the project more valuable than without them. They are termed real options as they provide a claim on real assets. Real options theory can be applied to a variety of projects including infrastructure projects, natural resource projects, research and development activities, expansion of existing projects, testing new technologies and penetration into new markets.

\section{Real Options Literature}

Real options analysis arose due to the need to introduce flexibility into managerial decision making processes and the limitations of capital budgeting techniques as discussed in Schwartz and Trigeorgis (2004). Early critics (e.g., Dean (1951), Hayes and Abernathy (1980), Hayes and Garvin (1982)) argued that standard discounted cash flow (DCF) analysis may lead to undervaluation of investment opportunities as strategic considerations associated with a project were overlooked.

Decision scientists (Hertz (1964), Magee (1964)) thought the problem was the application of incorrect valuation methods and used decision tree analysis to capture the additional value from flexibility in decision making. Myers (2004) argued that undervaluation of investments was a combination of mis-specified DCF analysis and the inability of DCF analysis to value investments with a range of operating or strategic options.

Despite the fact that real options analysis is a relatively new field, there is an extensive body of work available on an alternative conceptual real options framework for capital budgeting decisions. 
The development of quantitative models for real options analysis originated largely from the seminal work of Black and Scholes (1973) and Merton (1973) in pricing financial options as discussed in Schwartz and Trigeorgis (2004). Cox, Ross, and Rubenstein's (1979) binomial approach provided a simple valuation method for discrete time analysis of options. Murgrabe (1978) valued an option to exchange one risky asset for another. Johnson (1987) analysed options on the maximum (or minimum) of several risky assets.

These papers opened the potential to analyse a generic range of options (e.g., abandon or salvage, switch between inputs/outputs). Geske (1979) valued a compound option (i.e., an option that leads to another embedded option) which, in principle, is useful for valuing growth opportunities after an initial investment is undertaken. Carr (1988) valued sequential (compound) exchange options, involving an option to acquire a subsequent option to exchange the underlying asset for another risky alternative.

This provided the basis to value more complex projects that involved a series of investment outlays (that switch between alternative states of operation), and strategic inter-project dependencies. However, while real options analysis has focused on strategic managerial decision making and capital budgeting, it appears that literature on its application to economic evaluation in a government policy context is quite limited.

\section{Principles of Real Option Analysis}

The real options method applies financial options theory to quantify the value of management flexibility in a world of uncertainty. Similar to a financial option - that gives the holder to right, but not the obligation, to buy or sell a share at a particular date at a specified price - a real option gives the holder the right to take decisions regarding a physical asset at a pre-specified cost or prespecified time over the life of the option. Real options analysis allows decision makers to increase project value by identifying and taking advantage of opportunities to maximise gains or minimise losses in a dynamic marketplace.

The variables used to estimate the value of a financial option can be related to their corresponding variables in a real options analysis. The development of a bauxite resource can be used to illustrate the key similarities in Table 1.

\section{Table 1: Comparison real and financial options}

\begin{tabular}{|l|l|l|}
\hline Financial call option & Variable & Real options to develop a bauxite resource \\
\hline Stock price & $\mathrm{S}$ & Net present value of developed bauxite resource \\
\hline Exercise price & $\mathrm{X}$ & Present value of expenditure to develop bauxite resource \\
\hline Time to expiration & $\mathrm{T}$ & Time remaining on the development lease, or time to first bauxite \\
\hline Risk free-interest rate & $\mathrm{rf}$ & Risk free interest rate \\
\hline Volatility of stock price & Theta & Volatility in cash flows from bauxite resource \\
\hline Dividends foregone & Delta & Revenue of profits foregone. \\
\hline
\end{tabular}

Source: Oilfield Review, Winter 2003/04 
However there are some key differences between a real option and financial option that are highlighted below.

- The exercise price of a financial option is usually fixed, but the price of a real option is usually dependent on development costs may fluctuate depending on market conditions.

- With a financial option the uncertainty is external as the arrangement is between the option buyer and option seller; neither of whom can directly influence the rate of return on a company's shares. In contrast, a company that has a real option can influence the value of the underlying asset by developing new and more efficient technologies for the asset.

- Real options are often valued using financial options techniques, however real options tend to be far more complicated to value than financial options.

The real options method is a highly effective technique for the valuation and management of strategic investments. Managerial flexibility is valuable under certain circumstances (Copeland et al (2002), p402):

1. There is a high degree of uncertainty about the future and it is very likely that new information will be received over the period of analysis.

2. There is a high degree of managerial flexibility, which allows managers to respond to this new information.

3. NPV without flexibility is near zero. If the project is neither obviously good nor bad, flexibility to change course is more likely and thus more valuable.

Table 2: Value of Managerial Flexibility

\begin{tabular}{|c|c|c|c|}
\hline & & \multicolumn{2}{|c|}{ Likelihood of receiving new information } \\
\hline & & Low & High \\
\hline \multirow{3}{*}{$\begin{array}{l}\text { Ability of Managers } \\
\text { to Respond }\end{array}$} & \multirow{2}{*}{ High } & Moderate & High \\
\hline & & flexibility value & flexibility value \\
\hline & Low & $\begin{array}{l}\text { Low } \\
\text { flexibility value }\end{array}$ & $\begin{array}{l}\text { Moderate } \\
\text { flexibility value }\end{array}$ \\
\hline
\end{tabular}

Source: Copeland et al (2000), p402

\section{Option valuation using Black Scholes}

In 1973 Fischer Black and Myron Scholes published the Black Scholes formula for the valuation of financial options. They established that the value of an option could be estimated by constructing a replicating portfolio consisting of a number of shares in the underlying asset and a number of risk free bonds. Prices of bonds and underlying shares are directly observable in the financial market so the value of the replicating portfolio can be directly observed.

The existence of a replicating portfolio implies there is a combination of the option and underlying asset that is risk free. Therefore the risk free rate can be used during the option pricing calculation and is usually taken as the interest rate on a government guaranteed financial instrument like a Commonwealth Treasury Bond. 
The Black Scholes formula estimates values for a call price (c) or put price (p) as follows;

$$
\begin{gathered}
c=s \Phi\left(d_{1}\right)-x e^{-r t} \Phi\left(d_{2}\right) \\
p=x e^{-r t} \Phi\left(-d_{2}\right)-s \Phi\left(-d_{1}\right)
\end{gathered}
$$

where:

$$
\begin{gathered}
d_{1}=\frac{\log (s / x)+\left(r+\sigma^{2} / 2\right) t}{\sigma \sqrt{t}} \\
d_{2}=d_{1}-\sigma \sqrt{t}
\end{gathered}
$$

Here, log denotes the natural logarithm, and:

- $s=$ the price of the underlying stock

- $x=$ the strike price

- $r=$ the continuously compounded risk free rate

- $t=$ the time in years until the expiration of the option

- $\sigma=$ the implied volatility for the underlying stock

- $\Phi=$ the standard normal cumulative distribution function

\section{Valuing a Real Option using Black Scholes - Oil Development}

An oil developer is attempting to value its mining licence on a block of oil rich land in Western Australia. Paying the licence fee is equivalent to an acquiring an option that gives the developer the right but not obligation to develop the land any time during the 15 year mining licence. Initial geological studies indicate that the block is expected to contain $50 \mathrm{~m}$ barrels of oil with an estimated present value of $\$ 10$ per barrel. The cost of developing the field in present value terms is $\$ 600 \mathrm{~m}$.

Using a static DCF analysis the value of the oil development is:

$$
\text { PV (Oil Revenue }) \text { - PV (Development Cost })=\$ 500 \mathrm{~m}-\$ 600 \mathrm{~m}=-\$ 100 \mathrm{~m}
$$

Based on a static DCF analysis the project is unlikely to proceed as the developer cannot achieve the required rate of return on capital invested. However a static DCF analysis ignores that decisions can be made about sources of uncertainty that relate to the quantity of recoverable oil and the price of oil. It is possible to make reasonable estimates of the quantity of hydrocarbons based on sites with similar geological characteristics and analyse market data on the volatility of oil prices. Analysis of these two sources of uncertainty results in a 30\% standard deviation around the growth rate of net cash inflows.

Holding the option requires an annual payment to the State Government $(\$ 15 \mathrm{~m})$ to maintain the 
right to develop the reserve. This effectively represents a dividend type payout of 3\% (15/500) of the asset value.

Using the Black Scholes formula, but this time valuing a real option rather than a stock option, gives a real option value of $\$ 150.4 \mathrm{~m}$. In this case the value of the flexibility of being able to invest if and when uncertainties are resolved is worth $\$ 250.4 \mathrm{~m}$

PV $($ Option $)=$ PV $($ Flexibility $)-P V($ Static DCF $)=\$ 150.4 \mathrm{~m}-(-\$ 100 \mathrm{~m})=\$ 250.4 \mathrm{~m}$

Figure 1: Oil Development, Application of Black Scholes Option Pricing Formula

\begin{tabular}{llll}
\hline \multicolumn{2}{l}{$\begin{array}{l}\text { APPLICATION OF BLACK } \\
\text { SCHOLES }\end{array}$} & $\mathbf{( \$ \mathbf { m } )}$ & \\
& & \\
Asset value & 500 & $\mathrm{~K} 4$ & \\
Investment cost & 600 & $\mathrm{~K} 5$ & \\
Expected term of option & 15 & $\mathrm{~K} 6$ & \\
Risk-free rate & $5.00 \%$ & $\mathrm{~K} 7$ & \\
Volatility & $30 \%$ & $\mathrm{~K} 8$ & \\
Dividends rate & $3.00 \%$ & $\mathrm{~K} 9$ & \\
Calculated variable & 0.68223 & $\mathrm{~K} 10$ & $\left(\mathrm{LN}((+\mathrm{K} 4 * \mathrm{EXP}(-\mathrm{K} 9 * \mathrm{~K} 6)) / \mathrm{K} 5)+\left(\mathrm{K} 7+\mathrm{K} 8{ }^{\wedge} 2 / 2\right) * \mathrm{~K} 6\right) /(\mathrm{K} 8 * \mathrm{SQRT}(\mathrm{K} 6))$ \\
Calculated variable & -0.4797 & $\mathrm{~K} 11$ & $\mathrm{~K} 10-\mathrm{K} 8 * \mathrm{SQRT}(\mathrm{K} 6)$ \\
Estimated option value & 150.4 & & $(+\mathrm{K} 4 * \mathrm{EXP}(-\mathrm{K} 9 * \mathrm{~K} 6)) * \mathrm{NORMSDIST}(\mathrm{K} 10)-\mathrm{K} 5 * \mathrm{EXP}(-$ \\
& & & $\mathrm{K} 7 * \mathrm{~K} 6) * \mathrm{NORMSDIST}(\mathrm{K} 11)$ \\
\end{tabular}

\section{Discounted Cash Flow Analysis}

Discounted cash flow analysis is an accepted method for valuing assets and evaluating investment proposals (e.g. building a refinery). Using this technique expected cash flows (revenues, capital costs, operating costs) are discounted using the weighted average cost of capital (WACC) that represents the opportunity cost of investors funds or some estimate of the social opportunity cost of capital where non-commercial projects are funded by government. However with DCF analysis decisions regarding future periods are made today and this may fail to account for flexibility in business decisions (Triantis and Hodder (1990), Hayes and Abernathy (1980)).

Specifically, undertaking large scale infrastructure and resource projects in a competitive global market involves a high degree of uncertainty and may require a more complex analysis than using a simple discounted cash flow (DCF) technique. DCF implicitly assumes that investment decisions and projected cash flow scenarios, and the requisite assumptions about market demand, commodity prices, general economic conditions and the risk profile of the project can all made deterministically in period 0 .

In these circumstances it is possible that a DCF analysis may understate or overstate the value of an investment as there may be inherent values in exercising options to bring forward, delay or abandon development of a project. This is often critical as resource and infrastructure projects involve large capital outlays that are usually irreversible or sunk and inherently carry a high degree of risk. Where sponsors of these projects seek government assistance, this technique may not produce an estimate robust enough to determine what is the appropriate level of assistance. 
There are a range of limitations to DCF analysis that are well known. The key limitations are:

- DCF analysis is static in nature. It assumes that the project as planned is fixed and irreversible, and it follows that original plan irrespective of changing market conditions. However, management can actually change its plans as market conditions change and uncertainties are resolved. In these cases it may be possible to perform another DCF to reflect the changed project parameters; however it may already to too late to influence basic project decisions.

- DCF assumes that future cash flows are deterministic and predictable. In practice, it is often difficult to estimate cash flows and DCF can understate or overstate cash flows for certain types of projects. While sensitivity analysis is one way to enhance the level of information provided by a DCF analysis, this only tests the extent to which the project NPV will change when key project parameters (e.g. exchange rate, commodity prices, operating costs) are shocked. Sensitivity analysis still retains the underlying assumptions about future states of the world inherent in NPV analysis.

- DCF techniques are limited in valuing companies with significant growth opportunities. For example, DCF analysis typically relates corporate value to the present value of the future stream of earnings a company might generate. IF the company has some significant growth opportunities, it might be more useful to think of the company's value as its normalised current earnings (discounted by the opportunity cost of capital) plus the net present value of future growth opportunities - that firm's options to invest in the second stage, third stage or later stage projects.

- DCF is not helpful for valuing results from pure research and development activities as the benefits often accrue in the future, and there may be a range of future research options that could be pursued.

In some instances, probabilities based on information known today are used to assign weights to the outcomes of future states. That is, expected values are used to construct a DCF analysis. To the extent that this valuation is used together with a real options value, care needs to be taken to ensure that increased value identified in the option value is not already captured in the expected value analysis. Conceptually, it may be preferable to model on state of nature and look at the option value when another state is achieved, rather than having a weighted average of different states of nature in the analysis.

\section{V.Subsidising a Resource Extraction Process}

This section looks at a simple example of how the presentation of a commercial decision about whether to invest in a coal seam methane project may affect the level of financial assistance a government might provide to that project. The example demonstrates a key weakness in standard discounted cash flow analysis using expected values, where it is implicitly assumed that future information has no value or is not acted upon. The inherent assumption is that all investment and operational decisions are set at time $\mathrm{t}=0$ for the life of the project. This raises issues where government support for the project is sought.

Following Brennan and Schwartz (1985), a resource firm must decide whether to invest to develop a coal seam methane resource, assuming the investment is irreversible, in that after development management cannot disinvest and recover the expenditure. As a simplifying 
assumption, suppose development and extraction can be started immediately, requiring an investment outlay (I) of $\$ 20 \mathrm{~m}$. There are no variable extraction costs. As a further simplifying assumption, the coal seam methane reserves and the production profile $(\mathrm{Qt})$, over time $t$, is known ahead of time: production in year $1(\mathrm{Q} 1)$ is estimated to be 50,000 barrels, and production in year 2 (Q2) is estimated to be 100,000 barrels. This information is known with a reasonable amount of certainty based on geo-technical studies.

In this example, uncertainty over the value of the project is closely related to the dynamics in oil and gas prices. Currently, oil is assumed to be around $\$ 120$ per barrel; next year, the price will change. For simplicity, we assume two possible end-of-period prices after period one: price increasing (with a multiplicative factor $\mathrm{u}=1.25$ ) to $\mathrm{S}+=\$ 150$; or price decreasing (with a multiplicative factor $\mathrm{d}=0.8$ ) to a value of $\mathrm{S}-=\$ 96$. Both prices are equally likely. That is, $\mathrm{Pu}=\mathrm{Pd}$ $=0.5$. In the subsequent year $(t=2)$, prices may rise or decrease again, and the same multiplicative factors are assumed to apply.

Table 3 summarizes the possible oil prices $(\mathrm{S})$, extraction quantities $(\mathrm{Q})$, and the resulting operating cash flows, $\mathrm{CF}=\mathrm{P} \times \mathrm{S} \times \mathrm{Q}$. Expected operating cash flows (ECF) are based on the probability of those cash flows occurring at $t=0$. Suppose further that the risk-free interest rate $(r)$ is $6 \%$ per year.

Table 3: Quantities, Prices and Operating Cash Flows

\begin{tabular}{|c|c|c|c|c|c|c|}
\hline Period & $\begin{array}{c}\text { State } \\
\text { (Nature) }\end{array}$ & $\begin{array}{c}\text { Probability } \\
\mathbf{P}\end{array}$ & $\begin{array}{c}\text { Price } \\
\text { US\$/bbl } \\
\mathbf{S}\end{array}$ & $\begin{array}{c}\text { Quantity } \\
\mathbf{0 0 0} \mathbf{b b l} \\
\mathbf{Q}\end{array}$ & $\begin{array}{c}\text { Operating Cash } \\
\text { Flows } \\
\mathbf{\$ M} \\
\mathbf{C F}\end{array}$ & $\begin{array}{c}\text { Expected } \\
\text { Operating Cash } \\
\text { Flows } \\
\mathbf{\$ M} \\
\mathbf{E C F}\end{array}$ \\
\hline 0 & current & 1.0 & $\$ 120$ & 0 & $-\$ 20.00$ & $-\$ 20.00$ \\
\hline 1 & high & 0.5 & $\$ 150$ & 50 & $+\$ 7.50$ & $+\$ 3.75$ \\
\hline 1 & low & 0.5 & $\$ 96$ & 50 & $+\$ 4.80$ & $+\$ 2.40$ \\
\hline 2 & high, high & 0.25 & $\$ 188$ & 100 & $+\$ 18.76$ & $+\$ 4.69$ \\
\hline 2 & high, low / low, high & 0.5 & $\$ 120$ & 100 & $+\$ 12.00$ & $+\$ 6.00$ \\
\hline 2 & low, low & 0.25 & $\$ 77$ & 100 & $+\$ 7.68$ & $+\$ 1.92$ \\
\hline
\end{tabular}

Note: Numbers have been rounded.

In a simple two-period CBA, the net present value is the discounted sum of the expected cash flows. This is simply the weighted average of two alternative scenarios. The implicit assumption is that the project will proceed in Year 2 irrespective of any further information.

NPV is the maximum, decided today, of the expected discounted cash flows or zero. While the option value is the expected values of the maximums - decided when the information arrives - of the discounted cash flows in each future state of nature, or zero.

Calculating the expected NPV $(\$ \mathrm{~m})$ :

$=\operatorname{MAX}(\mathrm{t}=0)[$ Expected cash flows / discount rate, 0$]$

$=-\$ 20.00+(\$ 3.75+\$ 2.40) / 1.06$

$+(\$ 4.69+\$ 6.00+\$ 1.92) / 1.06^{\wedge} 2$

$=-\$ 20.00+(\$ 3.54+\$ 2.26)$

$+(\$ 4.17+\$ 5.34+\$ 1.71)$ 


$$
\begin{aligned}
& =-\$ 20.00+(\$ 5.80)+(\$ 11.22) \\
& =\operatorname{MAX}(\mathrm{t}=0)[-\$ 2.98,0] \\
& =0
\end{aligned}
$$

Under standard NPV decision criteria, the expected cash flows produce a negative NPV of $\$ 2.98 \mathrm{~m}$. Therefore the project would not proceed and there would be a zero NPV.

However, this ignores the impact from changes in future oil prices, which is possible to be valued as an option. Here we look at the situation where the project is simply abandoned if the NPV is negative in period one or period one and period two.

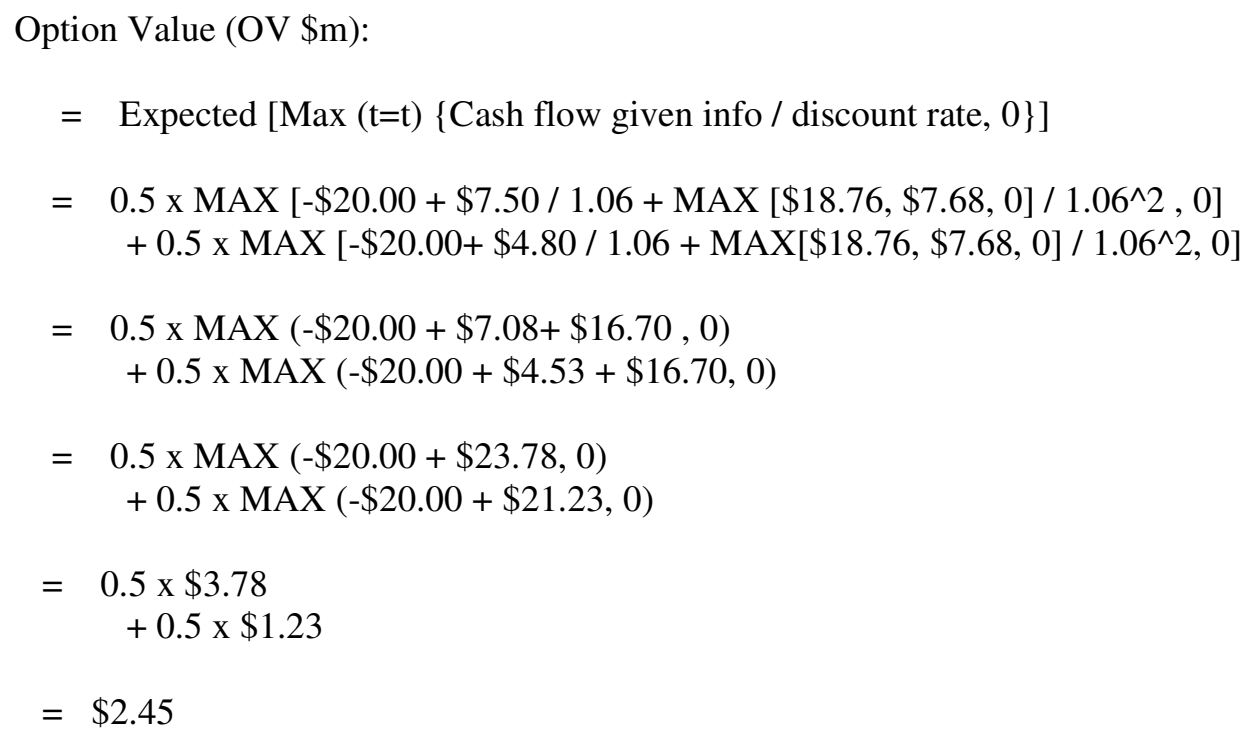

Consequently the value of flexibility is the difference between the Option Value and the Net Present Value, namely $\$ 5.53 \mathrm{~m}$.

Consider a policy context where a government is evaluating broader economic impacts surrounding the project. If it is presented with a NPV analysis, it may well conclude that a private proponent would not proceed with the project. The government may consider providing up front financial assistance of $\$ 2.98 \mathrm{~m}$ to secure a set of positive externalities if it considered the present value of these external benefits were of equal or greater value.

However, by not considering the real option embedded in the coal seam methane operation - an option to abandon the project - the Government may simply be unnecessarily subsidising a project that is actually worth $+\$ 2.45 \mathrm{~m}$ to its private sector proponent.

\section{Valuing Royalties in a Government Budget}

An application of real options analysis to mineral resource development is demonstrated following the approach by Bailey et al. (2003). It is possible to extend the analysis to derive an estimate 
of the royalty payments to the Government based on the real options valuation of the project. By not considering the inherent option value associated with managerial flexibility - e.g., option to abandon, option to expand, option to defer - royalty payments from a mineral resource development could be underestimated. This concept is illustrated using a new coal development.

A major coal producer has put forward a proposal to develop a large coal resource located in central Queensland. However the value of the project is contingent on a range of factors:

- the extraction process is new and has not been tested at the commercial level;

- the development is greenfield and involves significant capital expenditure; and

- the company cannot accurately predict or control world coal prices that are quite variable.

To develop the coal resource requires large capital investment $(\$ 525 \mathrm{~m})$ and the company has concerns about the long term economic viability of the project. The net present value of the project using discounted cash flow analysis is $\$ 293.9 \mathrm{~m}$ at a $12 \%$ real discount rate. Project capital expenditure, operating expenditure and sales revenue is reported in Table 4 over a 42 year project life.

Table 4: Coal Development: Project NPV and Underlying Cash Flows (\$M)

\begin{tabular}{|l|r|r|r|r|r|r|r|r|r|}
\hline & $\mathbf{N P V} \mathbf{( \$ \mathbf { m } )}$ & $\mathbf{2 0 0 8}$ & $\mathbf{2 0 0 9}$ & $\mathbf{2 0 1 0}$ & $\mathbf{2 0 1 1}$ & $\mathbf{2 0 1 2}$ & $\mathbf{2 0 1 3}$ & $\mathbf{2 0 1 4}$ & $\mathbf{2 0 1 5 - 5 0}$ \\
\hline Initial capital expenditure & $-\$ 419.3$ & $-\$ 50$ & $-\$ 120$ & $-\$ 155.0$ & $-\$ 150.0$ & $-\$ 50.0$ & & & \\
\hline Operating costs & $-\$ 576.1$ & $-\$ 50.0$ & $-\$ 65.0$ & $-\$ 65.0$ & $-\$ 65.0$ & $-\$ 65.0$ & $-\$ 65.0$ & $-\$ 65.0$ & $-\$ 572.30$ \\
\hline Revenue & $\$ 1,289.3$ & $\$ 0.0$ & $\$ 25.0$ & $\$ 45.0$ & $\$ 90.0$ & $\$ 250.0$ & $\$ 250.0$ & $\$ 250.0$ & $\$ 1,635.0$ \\
\hline Net Cash Flow & $\$ 293.9$ & $-\$ 100.0$ & $-\$ 160.0$ & $-\$ 175.0$ & $-\$ 125.0$ & $\$ 135.0$ & $\$ 185.0$ & $\$ 185.0$ & $\$ 1,062.8$ \\
\hline Net Present Value @ 12\% & $\mathbf{\$ 2 9 3 . 9}$ & & & & & & & & \\
\hline Internal Rate of Return & $\mathbf{2 4 \%}$ & & & & & & & & \\
\hline
\end{tabular}

Despite potentially being a lucrative project the company has doubts over the long term economic viability of the resource - especially given the large upfront capital outlays - and negotiates with another mineral developer to take over the project for an upfront payment $(\$ 100 \mathrm{~m})$ and reimburse developments costs to date if a decision is taken by the producer to exit the project at any stage of the development cycle.

The binomial approach for discrete time analysis of options is used to determine the inherent value - in addition to the project net present value - derived from flexibility to exit the development at any stage. The underlying asset is the resource project NPV. The NPV is assumed to exhibit a log normal distribution so the volatility of the asset is based on the logarithm of the future cash flows. It is assumed that the annual volatility of the DCF model is 55\% including all types of risk.

Figure 2 shows the binomial lattice for the asset and the valuation and decision lattice. The underlying lattice of the asset is constructed using single year time steps over 5 years. The risk free rate for the five year period under consideration is 5\%. The underlying asset value excluding the flexibility from exit is $\$ 293.9 \mathrm{~m}$. 
Figure 2: Underlying Asset, Valuation \& Decision Lattices for Coal Development

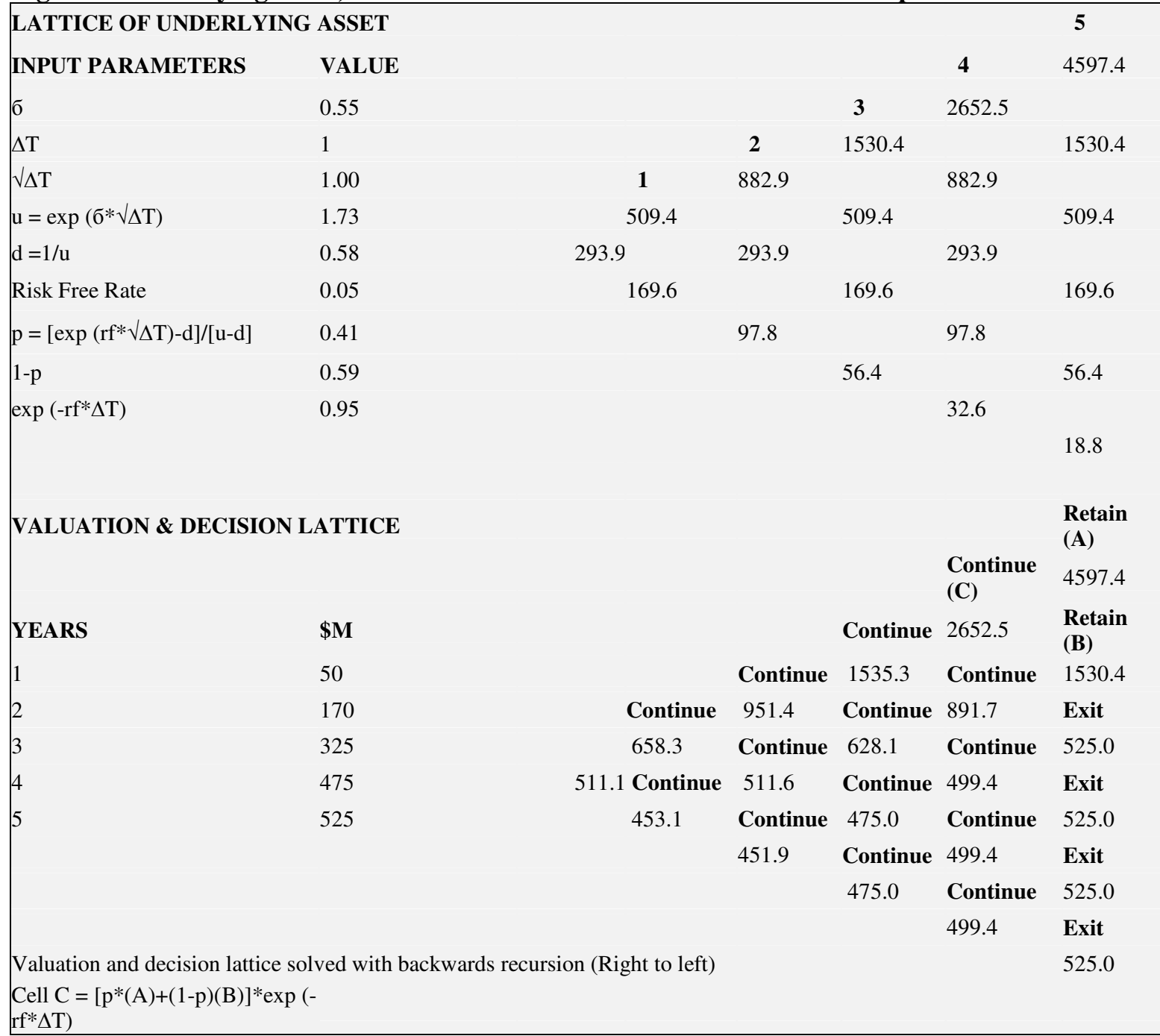

Solving the valuation and decision lattice iteratively - from right to left - shows that the flexibility of an exit option raises the value of the project NPV to $\$ 511.1 \mathrm{~m}$. On this basis the mineral resource developer would be willing to offer up to $\$ 217.2 \mathrm{~m}$ to another developer to retain the flexibility to exit the project.

The above analysis identifies the potential to underestimate expected royalties from a project with an embedded option. Under the static DCF analysis the project NPV was $\$ 293.9 \mathrm{~m}$ and the present value of sales revenues (i.e. coal exports) is $\$ 1.289 \mathrm{~m}$. Using a royalty rate of $10 \%$ the NPV of royalty collected is $\$ 128.9 \mathrm{~m}$. However the same project with an embedded option has a valuation in NPV terms of $\$ 511.1 \mathrm{~m}$.

To the extent that the option value represents increased coal export revenues, $10 \%$ of this amount would reflect the option value of government revenues from project royalty payments. If the project NPV of $\$ 511.1 \mathrm{~m}$ was due to higher coal prices - project revenue (in NPV terms) would increase to $\$ 1507.2 \mathrm{~m}$ - and royalty to collections to $\$ 150.7 \mathrm{~m}$. In this case, the static NPV estimate 
is likely to lead to an underestimate of future budget revenues from this project.

\section{Subsidising the Acquisition of Additional Environmental Benefits}

Strong sales of conventional automobiles are adding a significant amount of greenhouse gasses (GHGs) to the atmosphere. The Federal Government has a policy of encouraging early adoption of hybrid automotive technology. The potential long term economic benefits of reduced greenhouse gas emissions from adopting hybrid automobile technology are significant as there were $11.5 \mathrm{~m}$ registered motor vehicles in Australia (ABS 9309) in March 2007. If emissions were reduced by 1 tonne per year for each registered motor vehicle with an assumed \$50/tonne price for CO2-e, this could generate a gross benefit to the Australian economy of $\$ 575 \mathrm{~m}$ annually.

Recent advice from the government's greenhouse advisors suggests that a production subsidy on automobiles might increase the amount of GHGs saved. In effect the government is purchasing an environmental service - an increased reduction in GHGs. Given a tight budget constraint, the government only has $\$ 35 \mathrm{~m}$ available to achieve these reductions. The government's advisors posit there are two possible GHG reduction scenarios that might arise if this subsidy is spent on the automotive industry based either on a low (L) vehicle uptake rate, which has a $35 \%$ chance of occurring or a high $(\mathrm{H})$ vehicle uptake rate which has a $65 \%$ chance of occurring. However, detailed results are unlikely to be known for another 12 months.

It is possible to construct an expected NPV that incorporates the net cash flows associated with a high vehicle uptake rate $(\mathrm{P}(\mathrm{H})=65 \%)$ and a low vehicle uptake rate $(\mathrm{P}(\mathrm{L})=35 \%)$. This is shown in Table 5. First, though, note that the NPV(L) is $-\$ 21.1 \mathrm{~m}$, which poses a serious risk to government in terms of achieving a successful outcome, while the NPV $(\mathrm{H})$ is $+\$ 11.2 \mathrm{~m}$.

The expected NPV analysis that combines the NPVs based on low and high uptake rates produces a result of $-\$ 9.8 \mathrm{~m}$. On this basis, government consideration of support would be ruled out. However, the expected NPV analysis critically assumes that no new information is obtained over the period of analysis (2008-2018).

Suppose that additional research becomes available in 2009 that confirms either the high or low scenario. That information has a value today.

Table 5 sets out a static discounted cash flow analysis and compares it to an option valuation. 
Table 5: Hybrid Car Subsidy, Static DCF and Option Valuation (\$m)

\begin{tabular}{|c|c|c|c|c|c|c|c|c|c|c|c|c|}
\hline \begin{tabular}{|l|} 
Hybrid Car \\
Technology
\end{tabular} & & 2008 & 2009 & 2010 & 2011 & 2012 & 2013 & 2014 & 2015 & 2016 & 2017 & 2018 \\
\hline Subsidy & $\$ \mathrm{~m}$ & -35 & & & & & & & & & & \\
\hline \multicolumn{13}{|l|}{ Uptake Rate } \\
\hline High & '000s vehicles & & 25 & 50 & 75 & 100 & 125 & 150 & 175 & 200 & 225 & 250 \\
\hline Low & ‘000s vehicles & & 10 & 20 & 30 & 40 & 50 & 50 & 50 & 50 & 50 & 50 \\
\hline Quantity saved/vehicle & CO2-e tonnes & & 1 & 1 & 1 & 1 & 1 & 1 & 1 & 1 & 1 & 1 \\
\hline High & CO2-e '000t & & 25 & 50 & 75 & 100 & 125 & 150 & 175 & 200 & 225 & 250 \\
\hline Low & CO2-e '000t & & 10 & 20 & 30 & 40 & 50 & 50 & 50 & 50 & 50 & 50 \\
\hline CO2-e Price & $\$ / \mathrm{CO} 2-\mathrm{e}$ & & 50 & 50 & 50 & 50 & 50 & 50 & 50 & 50 & 50 & 50 \\
\hline \multicolumn{13}{|l|}{ Value of CO2-e Saved } \\
\hline High & $\$ \mathbf{m}$ & & 1.25 & 2.5 & 3.75 & 5 & 6.25 & 7.5 & 8.75 & 10 & 11.25 & 12.5 \\
\hline Low & & & 0.5 & 1 & 1.5 & 2 & 2.5 & 2.5 & 2.5 & 2.5 & 2.5 & 2.5 \\
\hline \multicolumn{13}{|l|}{ Net Benefit Flow } \\
\hline High & & -35.0 & 1.3 & 2.5 & 3.8 & 5.0 & 6.3 & 7.5 & 8.8 & 10.0 & 11.3 & 12.5 \\
\hline Low & & -35.0 & 0.5 & 1.0 & 1.5 & 2.0 & 2.5 & 2.5 & 2.5 & 2.5 & 2.5 & 2.5 \\
\hline \multirow[t]{2}{*}{ Discount Rate } & $6 \%$ & & & & & & & & & & & \\
\hline & NPV & IRR & & & & & & & & & & \\
\hline High & 11.2 & $11 \%$ & & & & & & & & & & \\
\hline Low & -21.1 & $-8 \%$ & & & & & & & & & & \\
\hline \multicolumn{13}{|l|}{$\begin{array}{l}\text { Expected NPV } \\
\text { Analysis }\end{array}$} \\
\hline Expected Value High & $35 \%$ & -12.3 & 0.4 & 0.9 & 1.3 & 1.8 & 2.2 & 2.6 & 3.1 & 3.5 & 3.9 & 4.4 \\
\hline Expected Value Low & $65 \%$ & -22.8 & 0.3 & 0.7 & 1.0 & 1.3 & 1.6 & 1.6 & 1.6 & 1.6 & 1.6 & 1.6 \\
\hline Expected Value & & -35.0 & 0.8 & 1.5 & 2.3 & 3.1 & 3.8 & 4.3 & 4.7 & 5.1 & 5.6 & 6.0 \\
\hline Expected NPV & -9.8 & & & & & & & & & & & \\
\hline & & & & & & & & & & & & \\
\hline \multicolumn{13}{|l|}{ Options Analysis } \\
\hline \multicolumn{13}{|c|}{ Option Value $=$ Probability $($ High $) \times$ Max $($ High, 0$)+$ Probability $($ Low $) \times$ Max $($ Low, 0$)$} \\
\hline \multicolumn{3}{|l|}{ Probability Low Scenario } & $65 \%$ & & & & & & & & & \\
\hline \multicolumn{2}{|l|}{$\begin{array}{l}\text { Probability High } \\
\text { Scenario }\end{array}$} & & $35 \%$ & & & & & & & & & \\
\hline \multicolumn{2}{|l|}{ Max (High , 0) } & & 11.20 & & & & & & & & & \\
\hline \multicolumn{2}{|l|}{ Max $($ Low , 0) } & & 0.0 & & & & & & & & & \\
\hline OPTION & & & 7.28 & & & & & & & & & \\
\hline
\end{tabular}

The options analysis shows that achieving a high scenario has an NPV of $+\$ 7.28 \mathrm{~m}$ today.

Consequently, on the basis of achieving a future uncertain benefit, Government could actually look at providing a subsidy today to access future benefits from the high scenario. 


\section{VIII.Standard Treasury Approaches to Project Valuation}

Standard approaches to project evaluation by Australian governments generally do not refer to real options. Standard Treasury approaches to project valuation were reviewed:

- In Queensland, for example the State's main cost benefit analysis guide (Queensland Treasury (2006)) and the main environmental evaluation guide (Environmental Protection Agency (2003)) are silent in relation to real options.

- While the UK Treasury provides a definition in its Green Book (HM Treasury (2003), p104), it is silent on techniques for government practitioners.

- In New South Wales (NSW), the Government Guidelines for Economic Appraisal (2007) do not cover the application of real options techniques in the economic appraisal of projects. In concentrates on the standard approaches to project evaluation including cost benefit analysis, cost effective analysis, multi-objective analysis and economic impact analysis.

- The Victorian Department of Treasury and Finance Investment Evaluation and Policy Guidelines (1996) recommends financial analysis, sensitivity analysis, cost-effectiveness analysis, socio-economic impact analysis and distributional impacts analysis to evaluate a project. No reference is made to use of real options as part of appraising projects.

- The Western Australian Department of Treasury and Finance Project Evaluation Guidelines (2005) provide Government agencies with a technical and procedural framework for the evaluation of new and existing projects. These guidelines cover financial evaluation, economic evaluation and social impact analysis. Again, there is no discussion on the role of real options in evaluating a proposal from the public perspective.

The public sections of the websites for the remaining Australian State and Territory governments did not contain any information on the project evaluation process.

Overall, it is appears that public policy analysts in Australia are rarely directed to use real options techniques to evaluate the financial and economic merit of project proposals. Typical public sector economic evaluations tend to look at where projects are more likely to be preferred on a standard discounted cash flow/net present value basis. The following table is typical of the high level decision processes used.

Table 6: Typical Economic/Financial Decision Process

\begin{tabular}{|c|c|c|}
\hline & $\begin{array}{c}\text { Positive Financial Net Present } \\
\text { Value }\end{array}$ & Negative Financial Net Present Value \\
\hline Positive Economic Externalities & Accept proposal & $\begin{array}{l}\text { Accept if negative financial net present } \\
\text { value can be offset at a cost less than } \\
\text { the estimated positive externalities }\end{array}$ \\
\hline Negative Economic Externalities & $\begin{array}{l}\text { Accept if cost of addressing negative } \\
\text { externalities can be offset by positive } \\
\text { net present value }\end{array}$ & Reject Proposal \\
\hline
\end{tabular}

However, there are a range of circumstances under which a real options analysis may be warranted instead of a traditional NPV analysis. One set of circumstances looks at managerial flexibility and 
the likelihood of receiving new information. As Table 1 suggests, there is likely to be a high option value where there is a high likelihood of receiving new information and there is a high degree of management flexibility to be able to respond to that additional information.

Consequently, a revised decision process might be required, like one outlined in Table 7.

Table 7: Suggested Revised Economic/Financial Decision Process

\begin{tabular}{|l|c|c|}
\hline Positive Economic Externalities & $\begin{array}{c}\text { Positive Financial Net Present } \\
\text { Value }\end{array}$ & Negative Financial Net Present Value \\
\hline Negative Economic Externalities & $\begin{array}{c}\text { Accept proposal } \\
\text { Accept if cost of addressing negative } \\
\text { net present value AND any option } \\
\text { value embedded in the externalities }\end{array}$ & $\begin{array}{c}\text { Accept if negative financial net present } \\
\text { value can be offset at a cost less than } \\
\text { the estimated positive externalities } \\
\text { AND any option value embedded in the } \\
\text { project }\end{array}$ \\
\hline $\begin{array}{c}\text { significant posal UNLES the real option values } \\
\text { either for the proponent or for the } \\
\text { community (expressed as externalities) }\end{array}$ \\
\hline
\end{tabular}

This has significant implications for the direction of evidence-based public policy. To the extent that there is a significant real option value associated with a project or proposed government program, there is a risk that the direction of this option value may either support or cut across the preliminary net present value analysis that is undertaken.

\section{Conclusions}

There are a range of circumstances under which a real options analysis may be warranted instead of a traditional NPV analysis. One set of circumstances looks at managerial flexibility and the likelihood of receiving new information. There is likely to be a high option value where there is a high likelihood of receiving new information and there is a high degree of management flexibility to be able to respond to that additional information.

The above examples have shown that from a Government decision making perspective, projects that contain embedded option values for private proponents, if not valued by Government, may lead Government to conclude that financial assistance is warranted for the a project when it is not actually needed. A static DCF analysis is likely to underestimate the value of these projects is embedded options are not incorporated into the project valuation.

While the above examples have focused on resource and industry projects that are predominantly private sector projects, broader application of the real options analysis technique could see it used more in the social infrastructure and significant social project contexts - particularly in terms of siting new health services or education facilities. Also, as an owner of significant assets with the economy, government has a stewardship role. This could be enhanced by a more considered application of real options analysis in terms of maintenance and renewals planning as part of a broader strategic asset management approach. Further research in these areas is considered warranted. 


\section{References}

Australian Bureau of Statistics Motor Vehicle Census (2007) ABS 9309.0

Bailey,W. Bhandari, A. Faiz,S. Srinavasan, S. and Weeds, H. (2003) 'Unlocking the Value of Real Options' Oilfield Review Winter 2003, Vol. 15, No. 4, pp. 4-19

Bellalah, M. (2002) 'Valuation of commodity assets and the option to invest in the presence of stochastic prices and incomplete information', Conference Paper, 6th Annual Real Options Conference, Paphos, Cyprus, 4-6 July 2002

Boyle, G. and Irwin, T. (2004) 'A Primer on Real Options', New Zealand Institute for the Study of Competition and Regulation, 11 May 2004

Brandao, L.E.T. and Saraiva, E.C.G. (2007) 'Valuing Government Guarantees in Toll Road Projects', realoptions.org

Brennan, Michael and Eduardo Schwartz (1985) "Evaluating Natural Resource Investments" Journal of Business 58: 135-157.

Copeland, T. Koller, T. and Murrin, J. (2000) Valuation: Measuring and Managing the Value of Companies, Third Edition (University Edition), McKinsey \& Company, Inc., John Wiley \& Sons, Inc.

EPA (2003) Environmental Economic Evaluation: An Introductory Guide for Policymakers and Practitioners, Queensland Environmental Protection Agency

HM Treasury (2003) The Green Book: Appraisal and Evaluation in Central Government

Kruger, N.A. and Svensson, M. (2007) 'The Impact of Real Options on the Willingness to Pay for Mortality Risk Reductions' Working Paper No.9, 2007, Working Paper Series, Economics Department, Orebro University, Sweden

Leslie, K.J. and Michaels, M.P. (1997) 'The Real Power of Options', The McKinsey Quarterly, 1997, No.3, pp97 - $108<$

McCormack, J. Stern Stewart \& Co. and Sick, G. (2001) 'Valuing PUD Reserves; A Practical Application of Real Option Techniques', Bank of America, Journal of Applied Corporate Finance

New South Wales Treasury (2007) NSW Guidelines for Economic Appraisal, Policy and Guidelines Papers, Office of Financial Management

Osborne, C. (2008) 'Economist's Corner - Real Options Should Be Part of Our Thinking', The Way Ahead, Vol.4, No.1, Society of Petroleum Engineers , p24

Queensland Treasury (2006) Cost Benefit Analysis Guidelines - Achieving Value for Money in Public Infrastructure Service Delivery, Project Assurance Framework, Supplementary Guidance Material

Smit, H.T.J. and Trigeorgis, L. (2003) 'Real Options: Examples and Principles of Valuation and 
Strategy', School of Economics, Erasmus University Rotterdam

Schwartz, E.S. and Trigeorgis. L. (2004) Real Options and Investment Uncertainty Classical Readings and Recent Contributions, paperback edition, First MIT Press

Victorian Department of Treasury and Finance (1996) Investment Evaluation Policy and Guidelines

Western Australian Department of Treasury and Finance (2005) Project Evaluation Guidelines 


\title{
REAL OPTIONS: APPLICATIONS IN PUBLIC ECONOMICS
}

\author{
Mathew Thomas \\ Project Manager - Economic Advisory \\ Queensland Department of Tourism, \\ Regional Development and Industry \\ Brisbane, Australia \\ Phone: +61-7-3222-2966 \\ Email: mathew.thomas AT dtrdi.qld.gov.au
}

and

\author{
Craig Lawrence \\ Senior Economist \\ Connell Wagner Pty Ltd \\ Brisbane, Australia \\ Phone: +61-411-808-086 \\ Email: lawrencecr AT conwag.com
}

30 June 2008

\section{Disclaimer:}

The views expressed in this paper are solely those of the authors and do not reflect or represent the views of their respective employers. 


\title{
REAL OPTIONS: APPLICATIONS IN PUBLIC ECONOMICS
}

\begin{abstract}
This paper illustrates the use of real options principles to value prototypical resource and industry investment projects. It captures important competitive/strategic dimensions in a step-by-step analysis of investment decisions (options) under uncertainty. It compares and contrasts static discounted cash flow analysis (DCF) with real options analysis using three case studies. The initial example values a resource extraction process using static DCF and then compares the project valuation when future information is valued and acted upon. The second example considers a coal development and uses the binomial valuation approach to capture the option value associated with having the right but not the obligation to exit the development. It contrasts this valuation approach against static DCF and highlights that future royalty payments could be underestimated if based on the standard DCF valuation. The third example analyses the impact of providing a subsidy for hybrid vehicle production to accelerate potential uncertain environmental benefits. Lastly, the suitability of the standard financial and economic evaluation tools used by treasury agencies is considered when projects contain real options.
\end{abstract}

Key words: financial economics, investment decisions, public economics, externalities, subsidies, project evaluation

JEL Classification: G10, G11, H10, H23, H43 


\section{REAL OPTIONS: APPLICATIONS IN PUBLIC ECONOMICS}

\section{Introduction}

"Real option theory ... presumes that decision making is sequential and that decision makers may benefit from choosing options that seem sub optimal today but which increase flexibility at later times, leading to better decision making when more is known about the project." (HM Treasury (2003), p104)

Real option analysis is focused on describing uncertainty and, in particular, managerial flexibility inherent in many investment decisions. It takes on particular importance in uncertain and highly competitive global environments where investment decisions are frequently revised over time in response to unexpected market developments. Real options analysis gives the decision maker an opportunity but not the obligation to take future courses of action in relation to a project. Such options typically include the possibility to delay, expand, contract, or liquidate the project.

The availability of these real options creates inherent value, which makes the project more valuable than without them. They are termed real options as they provide a claim on real assets. Real options theory can be applied to a variety of projects including infrastructure projects, natural resource projects, research and development activities, expansion of existing projects, testing new technologies and penetration into new markets.

\section{Real Options Literature}

Real options analysis arose due to the need to introduce flexibility into managerial decision making processes and the limitations of capital budgeting techniques as discussed in Schwartz and Trigeorgis (2004). Early critics (e.g., Dean (1951), Hayes and Abernathy (1980), Hayes and Garvin (1982)) argued that standard discounted cash flow (DCF) analysis may lead to undervaluation of investment opportunities as strategic considerations associated with a project were overlooked.

Decision scientists (Hertz (1964), Magee (1964)) thought the problem was the application of incorrect valuation methods and used decision tree analysis to capture the additional value from flexibility in decision making. Myers (2004) argued that undervaluation of investments was a combination of mis-specified DCF analysis and the inability of DCF analysis to value investments with a range of operating or strategic options.

Despite the fact that real options analysis is a relatively new field, there is an extensive body of work available on an alternative conceptual real options framework for capital budgeting decisions. 
The development of quantitative models for real options analysis originated largely from the seminal work of Black and Scholes (1973) and Merton (1973) in pricing financial options as discussed in Schwartz and Trigeorgis (2004). Cox, Ross, and Rubenstein's (1979) binomial approach provided a simple valuation method for discrete time analysis of options. Murgrabe (1978) valued an option to exchange one risky asset for another. Johnson (1987) analysed options on the maximum (or minimum) of several risky assets.

These papers opened the potential to analyse a generic range of options (e.g., abandon or salvage, switch between inputs/outputs). Geske (1979) valued a compound option (i.e., an option that leads to another embedded option) which, in principle, is useful for valuing growth opportunities after an initial investment is undertaken. Carr (1988) valued sequential (compound) exchange options, involving an option to acquire a subsequent option to exchange the underlying asset for another risky alternative.

This provided the basis to value more complex projects that involved a series of investment outlays (that switch between alternative states of operation), and strategic inter-project dependencies. However, while real options analysis has focused on strategic managerial decision making and capital budgeting, it appears that literature on its application to economic evaluation in a government policy context is quite limited.

\section{Principles of Real Option Analysis}

The real options method applies financial options theory to quantify the value of management flexibility in a world of uncertainty. Similar to a financial option - that gives the holder to right, but not the obligation, to buy or sell a share at a particular date at a specified price - a real option gives the holder the right to take decisions regarding a physical asset at a pre-specified cost or prespecified time over the life of the option. Real options analysis allows decision makers to increase project value by identifying and taking advantage of opportunities to maximise gains or minimise losses in a dynamic marketplace.

The variables used to estimate the value of a financial option can be related to their corresponding variables in a real options analysis. The development of a bauxite resource can be used to illustrate the key similarities in Table 1.

\section{Table 1: Comparison real and financial options}

\begin{tabular}{|l|l|l|}
\hline Financial call option & Variable & Real options to develop a bauxite resource \\
\hline Stock price & $\mathrm{S}$ & Net present value of developed bauxite resource \\
\hline Exercise price & $\mathrm{X}$ & Present value of expenditure to develop bauxite resource \\
\hline Time to expiration & $\mathrm{T}$ & Time remaining on the development lease, or time to first bauxite \\
\hline Risk free-interest rate & $\mathrm{rf}$ & Risk free interest rate \\
\hline Volatility of stock price & Theta & Volatility in cash flows from bauxite resource \\
\hline Dividends foregone & Delta & Revenue of profits foregone. \\
\hline
\end{tabular}

Source: Oilfield Review, Winter 2003/04 
However there are some key differences between a real option and financial option that are highlighted below.

- The exercise price of a financial option is usually fixed, but the price of a real option is usually dependent on development costs may fluctuate depending on market conditions.

- With a financial option the uncertainty is external as the arrangement is between the option buyer and option seller; neither of whom can directly influence the rate of return on a company's shares. In contrast, a company that has a real option can influence the value of the underlying asset by developing new and more efficient technologies for the asset.

- Real options are often valued using financial options techniques, however real options tend to be far more complicated to value than financial options.

The real options method is a highly effective technique for the valuation and management of strategic investments. Managerial flexibility is valuable under certain circumstances (Copeland et al (2002), p402):

1. There is a high degree of uncertainty about the future and it is very likely that new information will be received over the period of analysis.

2. There is a high degree of managerial flexibility, which allows managers to respond to this new information.

3. NPV without flexibility is near zero. If the project is neither obviously good nor bad, flexibility to change course is more likely and thus more valuable.

Table 2: Value of Managerial Flexibility

\begin{tabular}{|c|c|c|c|}
\hline & & \multicolumn{2}{|c|}{ Likelihood of receiving new information } \\
\hline & & Low & High \\
\hline \multirow{3}{*}{$\begin{array}{l}\text { Ability of Managers } \\
\text { to Respond }\end{array}$} & \multirow{2}{*}{ High } & Moderate & High \\
\hline & & flexibility value & flexibility value \\
\hline & Low & $\begin{array}{l}\text { Low } \\
\text { flexibility value }\end{array}$ & $\begin{array}{l}\text { Moderate } \\
\text { flexibility value }\end{array}$ \\
\hline
\end{tabular}

Source: Copeland et al (2000), p402

\section{Option valuation using Black Scholes}

In 1973 Fischer Black and Myron Scholes published the Black Scholes formula for the valuation of financial options. They established that the value of an option could be estimated by constructing a replicating portfolio consisting of a number of shares in the underlying asset and a number of risk free bonds. Prices of bonds and underlying shares are directly observable in the financial market so the value of the replicating portfolio can be directly observed.

The existence of a replicating portfolio implies there is a combination of the option and underlying asset that is risk free. Therefore the risk free rate can be used during the option pricing calculation and is usually taken as the interest rate on a government guaranteed financial instrument like a Commonwealth Treasury Bond. 
The Black Scholes formula estimates values for a call price (c) or put price (p) as follows;

$$
\begin{gathered}
c=s \Phi\left(d_{1}\right)-x e^{-r t} \Phi\left(d_{2}\right) \\
p=x e^{-r t} \Phi\left(-d_{2}\right)-s \Phi\left(-d_{1}\right)
\end{gathered}
$$

where:

$$
\begin{gathered}
d_{1}=\frac{\log (s / x)+\left(r+\sigma^{2} / 2\right) t}{\sigma \sqrt{t}} \\
d_{2}=d_{1}-\sigma \sqrt{t}
\end{gathered}
$$

Here, log denotes the natural logarithm, and:

- $s=$ the price of the underlying stock

- $x=$ the strike price

- $r=$ the continuously compounded risk free rate

- $t=$ the time in years until the expiration of the option

- $\sigma=$ the implied volatility for the underlying stock

- $\Phi=$ the standard normal cumulative distribution function

\section{Valuing a Real Option using Black Scholes - Oil Development}

An oil developer is attempting to value its mining licence on a block of oil rich land in Western Australia. Paying the licence fee is equivalent to an acquiring an option that gives the developer the right but not obligation to develop the land any time during the 15 year mining licence. Initial geological studies indicate that the block is expected to contain $50 \mathrm{~m}$ barrels of oil with an estimated present value of $\$ 10$ per barrel. The cost of developing the field in present value terms is $\$ 600 \mathrm{~m}$.

Using a static DCF analysis the value of the oil development is:

$$
\text { PV (Oil Revenue }) \text { - PV (Development Cost })=\$ 500 \mathrm{~m}-\$ 600 \mathrm{~m}=-\$ 100 \mathrm{~m}
$$

Based on a static DCF analysis the project is unlikely to proceed as the developer cannot achieve the required rate of return on capital invested. However a static DCF analysis ignores that decisions can be made about sources of uncertainty that relate to the quantity of recoverable oil and the price of oil. It is possible to make reasonable estimates of the quantity of hydrocarbons based on sites with similar geological characteristics and analyse market data on the volatility of oil prices. Analysis of these two sources of uncertainty results in a 30\% standard deviation around the growth rate of net cash inflows.

Holding the option requires an annual payment to the State Government $(\$ 15 \mathrm{~m})$ to maintain the 
right to develop the reserve. This effectively represents a dividend type payout of 3\% (15/500) of the asset value.

Using the Black Scholes formula, but this time valuing a real option rather than a stock option, gives a real option value of $\$ 150.4 \mathrm{~m}$. In this case the value of the flexibility of being able to invest if and when uncertainties are resolved is worth $\$ 250.4 \mathrm{~m}$

PV $($ Option $)=$ PV $($ Flexibility $)-P V($ Static DCF $)=\$ 150.4 \mathrm{~m}-(-\$ 100 \mathrm{~m})=\$ 250.4 \mathrm{~m}$

Figure 1: Oil Development, Application of Black Scholes Option Pricing Formula

\begin{tabular}{llll}
\hline \multicolumn{2}{l}{$\begin{array}{l}\text { APPLICATION OF BLACK } \\
\text { SCHOLES }\end{array}$} & $\mathbf{( \$ \mathbf { m } )}$ & \\
& & \\
Asset value & 500 & $\mathrm{~K} 4$ & \\
Investment cost & 600 & $\mathrm{~K} 5$ & \\
Expected term of option & 15 & $\mathrm{~K} 6$ & \\
Risk-free rate & $5.00 \%$ & $\mathrm{~K} 7$ & \\
Volatility & $30 \%$ & $\mathrm{~K} 8$ & \\
Dividends rate & $3.00 \%$ & $\mathrm{~K} 9$ & \\
Calculated variable & 0.68223 & $\mathrm{~K} 10$ & $\left(\mathrm{LN}((+\mathrm{K} 4 * \mathrm{EXP}(-\mathrm{K} 9 * \mathrm{~K} 6)) / \mathrm{K} 5)+\left(\mathrm{K} 7+\mathrm{K} 8{ }^{\wedge} 2 / 2\right) * \mathrm{~K} 6\right) /(\mathrm{K} 8 * \mathrm{SQRT}(\mathrm{K} 6))$ \\
Calculated variable & -0.4797 & $\mathrm{~K} 11$ & $\mathrm{~K} 10-\mathrm{K} 8 * \mathrm{SQRT}(\mathrm{K} 6)$ \\
Estimated option value & 150.4 & & $(+\mathrm{K} 4 * \mathrm{EXP}(-\mathrm{K} 9 * \mathrm{~K} 6)) * \mathrm{NORMSDIST}(\mathrm{K} 10)-\mathrm{K} 5 * \mathrm{EXP}(-$ \\
& & & $\mathrm{K} 7 * \mathrm{~K} 6) * \mathrm{NORMSDIST}(\mathrm{K} 11)$ \\
\end{tabular}

\section{Discounted Cash Flow Analysis}

Discounted cash flow analysis is an accepted method for valuing assets and evaluating investment proposals (e.g. building a refinery). Using this technique expected cash flows (revenues, capital costs, operating costs) are discounted using the weighted average cost of capital (WACC) that represents the opportunity cost of investors funds or some estimate of the social opportunity cost of capital where non-commercial projects are funded by government. However with DCF analysis decisions regarding future periods are made today and this may fail to account for flexibility in business decisions (Triantis and Hodder (1990), Hayes and Abernathy (1980)).

Specifically, undertaking large scale infrastructure and resource projects in a competitive global market involves a high degree of uncertainty and may require a more complex analysis than using a simple discounted cash flow (DCF) technique. DCF implicitly assumes that investment decisions and projected cash flow scenarios, and the requisite assumptions about market demand, commodity prices, general economic conditions and the risk profile of the project can all made deterministically in period 0 .

In these circumstances it is possible that a DCF analysis may understate or overstate the value of an investment as there may be inherent values in exercising options to bring forward, delay or abandon development of a project. This is often critical as resource and infrastructure projects involve large capital outlays that are usually irreversible or sunk and inherently carry a high degree of risk. Where sponsors of these projects seek government assistance, this technique may not produce an estimate robust enough to determine what is the appropriate level of assistance. 
There are a range of limitations to DCF analysis that are well known. The key limitations are:

- DCF analysis is static in nature. It assumes that the project as planned is fixed and irreversible, and it follows that original plan irrespective of changing market conditions. However, management can actually change its plans as market conditions change and uncertainties are resolved. In these cases it may be possible to perform another DCF to reflect the changed project parameters; however it may already to too late to influence basic project decisions.

- DCF assumes that future cash flows are deterministic and predictable. In practice, it is often difficult to estimate cash flows and DCF can understate or overstate cash flows for certain types of projects. While sensitivity analysis is one way to enhance the level of information provided by a DCF analysis, this only tests the extent to which the project NPV will change when key project parameters (e.g. exchange rate, commodity prices, operating costs) are shocked. Sensitivity analysis still retains the underlying assumptions about future states of the world inherent in NPV analysis.

- DCF techniques are limited in valuing companies with significant growth opportunities. For example, DCF analysis typically relates corporate value to the present value of the future stream of earnings a company might generate. IF the company has some significant growth opportunities, it might be more useful to think of the company's value as its normalised current earnings (discounted by the opportunity cost of capital) plus the net present value of future growth opportunities - that firm's options to invest in the second stage, third stage or later stage projects.

- DCF is not helpful for valuing results from pure research and development activities as the benefits often accrue in the future, and there may be a range of future research options that could be pursued.

In some instances, probabilities based on information known today are used to assign weights to the outcomes of future states. That is, expected values are used to construct a DCF analysis. To the extent that this valuation is used together with a real options value, care needs to be taken to ensure that increased value identified in the option value is not already captured in the expected value analysis. Conceptually, it may be preferable to model on state of nature and look at the option value when another state is achieved, rather than having a weighted average of different states of nature in the analysis.

\section{V.Subsidising a Resource Extraction Process}

This section looks at a simple example of how the presentation of a commercial decision about whether to invest in a coal seam methane project may affect the level of financial assistance a government might provide to that project. The example demonstrates a key weakness in standard discounted cash flow analysis using expected values, where it is implicitly assumed that future information has no value or is not acted upon. The inherent assumption is that all investment and operational decisions are set at time $\mathrm{t}=0$ for the life of the project. This raises issues where government support for the project is sought.

Following Brennan and Schwartz (1985), a resource firm must decide whether to invest to develop a coal seam methane resource, assuming the investment is irreversible, in that after development management cannot disinvest and recover the expenditure. As a simplifying 
assumption, suppose development and extraction can be started immediately, requiring an investment outlay (I) of $\$ 20 \mathrm{~m}$. There are no variable extraction costs. As a further simplifying assumption, the coal seam methane reserves and the production profile $(\mathrm{Qt})$, over time $t$, is known ahead of time: production in year $1(\mathrm{Q} 1)$ is estimated to be 50,000 barrels, and production in year 2 (Q2) is estimated to be 100,000 barrels. This information is known with a reasonable amount of certainty based on geo-technical studies.

In this example, uncertainty over the value of the project is closely related to the dynamics in oil and gas prices. Currently, oil is assumed to be around $\$ 120$ per barrel; next year, the price will change. For simplicity, we assume two possible end-of-period prices after period one: price increasing (with a multiplicative factor $\mathrm{u}=1.25$ ) to $\mathrm{S}+=\$ 150$; or price decreasing (with a multiplicative factor $\mathrm{d}=0.8$ ) to a value of $\mathrm{S}-=\$ 96$. Both prices are equally likely. That is, $\mathrm{Pu}=\mathrm{Pd}$ $=0.5$. In the subsequent year $(t=2)$, prices may rise or decrease again, and the same multiplicative factors are assumed to apply.

Table 3 summarizes the possible oil prices $(\mathrm{S})$, extraction quantities $(\mathrm{Q})$, and the resulting operating cash flows, $\mathrm{CF}=\mathrm{P} \times \mathrm{S} \times \mathrm{Q}$. Expected operating cash flows (ECF) are based on the probability of those cash flows occurring at $t=0$. Suppose further that the risk-free interest rate $(r)$ is $6 \%$ per year.

Table 3: Quantities, Prices and Operating Cash Flows

\begin{tabular}{|c|c|c|c|c|c|c|}
\hline Period & $\begin{array}{c}\text { State } \\
\text { (Nature) }\end{array}$ & $\begin{array}{c}\text { Probability } \\
\mathbf{P}\end{array}$ & $\begin{array}{c}\text { Price } \\
\text { US\$/bbl } \\
\mathbf{S}\end{array}$ & $\begin{array}{c}\text { Quantity } \\
\mathbf{0 0 0} \mathbf{b b l} \\
\mathbf{Q}\end{array}$ & $\begin{array}{c}\text { Operating Cash } \\
\text { Flows } \\
\mathbf{\$ M} \\
\mathbf{C F}\end{array}$ & $\begin{array}{c}\text { Expected } \\
\text { Operating Cash } \\
\text { Flows } \\
\mathbf{\$ M} \\
\mathbf{E C F}\end{array}$ \\
\hline 0 & current & 1.0 & $\$ 120$ & 0 & $-\$ 20.00$ & $-\$ 20.00$ \\
\hline 1 & high & 0.5 & $\$ 150$ & 50 & $+\$ 7.50$ & $+\$ 3.75$ \\
\hline 1 & low & 0.5 & $\$ 96$ & 50 & $+\$ 4.80$ & $+\$ 2.40$ \\
\hline 2 & high, high & 0.25 & $\$ 188$ & 100 & $+\$ 18.76$ & $+\$ 4.69$ \\
\hline 2 & high, low / low, high & 0.5 & $\$ 120$ & 100 & $+\$ 12.00$ & $+\$ 6.00$ \\
\hline 2 & low, low & 0.25 & $\$ 77$ & 100 & $+\$ 7.68$ & $+\$ 1.92$ \\
\hline
\end{tabular}

Note: Numbers have been rounded.

In a simple two-period CBA, the net present value is the discounted sum of the expected cash flows. This is simply the weighted average of two alternative scenarios. The implicit assumption is that the project will proceed in Year 2 irrespective of any further information.

NPV is the maximum, decided today, of the expected discounted cash flows or zero. While the option value is the expected values of the maximums - decided when the information arrives - of the discounted cash flows in each future state of nature, or zero.

Calculating the expected NPV $(\$ \mathrm{~m})$ :

$=\operatorname{MAX}(\mathrm{t}=0)[$ Expected cash flows / discount rate, 0$]$

$=-\$ 20.00+(\$ 3.75+\$ 2.40) / 1.06$

$+(\$ 4.69+\$ 6.00+\$ 1.92) / 1.06^{\wedge} 2$

$=-\$ 20.00+(\$ 3.54+\$ 2.26)$

$+(\$ 4.17+\$ 5.34+\$ 1.71)$ 


$$
\begin{aligned}
& =-\$ 20.00+(\$ 5.80)+(\$ 11.22) \\
& =\operatorname{MAX}(\mathrm{t}=0)[-\$ 2.98,0] \\
& =0
\end{aligned}
$$

Under standard NPV decision criteria, the expected cash flows produce a negative NPV of $\$ 2.98 \mathrm{~m}$. Therefore the project would not proceed and there would be a zero NPV.

However, this ignores the impact from changes in future oil prices, which is possible to be valued as an option. Here we look at the situation where the project is simply abandoned if the NPV is negative in period one or period one and period two.

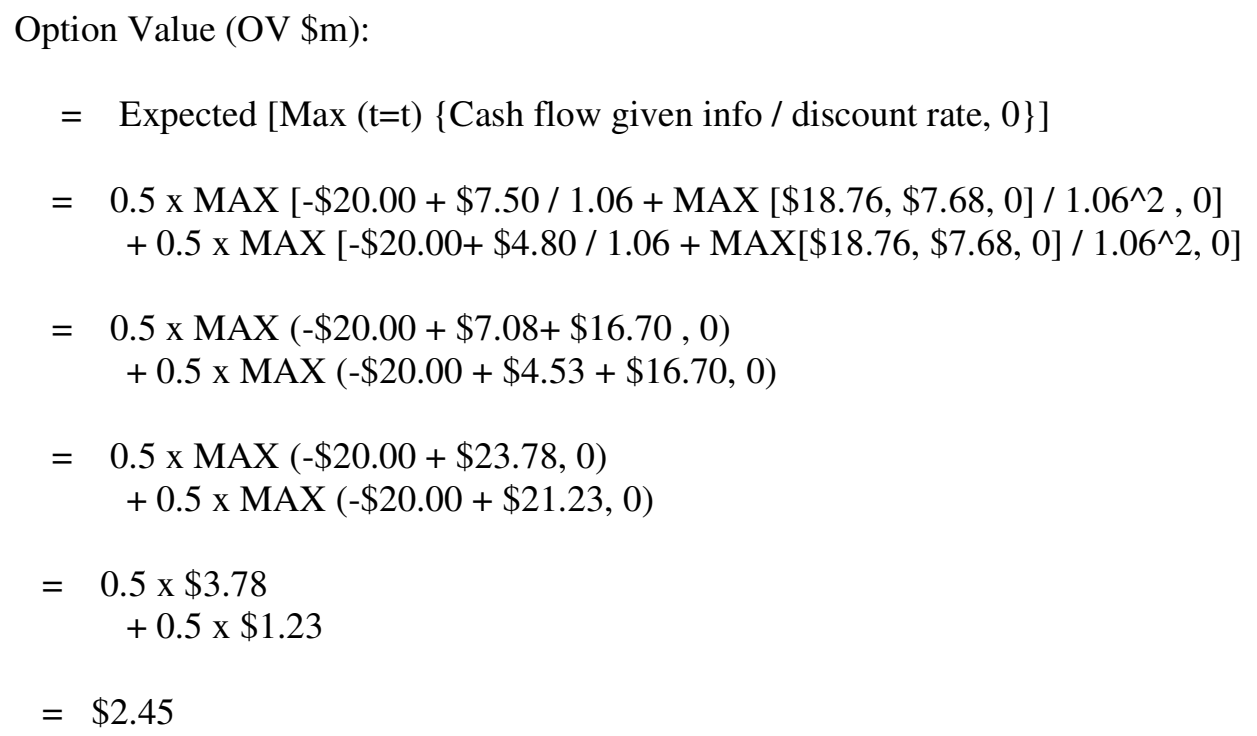

Consequently the value of flexibility is the difference between the Option Value and the Net Present Value, namely $\$ 5.53 \mathrm{~m}$.

Consider a policy context where a government is evaluating broader economic impacts surrounding the project. If it is presented with a NPV analysis, it may well conclude that a private proponent would not proceed with the project. The government may consider providing up front financial assistance of $\$ 2.98 \mathrm{~m}$ to secure a set of positive externalities if it considered the present value of these external benefits were of equal or greater value.

However, by not considering the real option embedded in the coal seam methane operation - an option to abandon the project - the Government may simply be unnecessarily subsidising a project that is actually worth $+\$ 2.45 \mathrm{~m}$ to its private sector proponent.

\section{Valuing Royalties in a Government Budget}

An application of real options analysis to mineral resource development is demonstrated following the approach by Bailey et al. (2003). It is possible to extend the analysis to derive an estimate 
of the royalty payments to the Government based on the real options valuation of the project. By not considering the inherent option value associated with managerial flexibility - e.g., option to abandon, option to expand, option to defer - royalty payments from a mineral resource development could be underestimated. This concept is illustrated using a new coal development.

A major coal producer has put forward a proposal to develop a large coal resource located in central Queensland. However the value of the project is contingent on a range of factors:

- the extraction process is new and has not been tested at the commercial level;

- the development is greenfield and involves significant capital expenditure; and

- the company cannot accurately predict or control world coal prices that are quite variable.

To develop the coal resource requires large capital investment $(\$ 525 \mathrm{~m})$ and the company has concerns about the long term economic viability of the project. The net present value of the project using discounted cash flow analysis is $\$ 293.9 \mathrm{~m}$ at a $12 \%$ real discount rate. Project capital expenditure, operating expenditure and sales revenue is reported in Table 4 over a 42 year project life.

Table 4: Coal Development: Project NPV and Underlying Cash Flows (\$M)

\begin{tabular}{|l|r|r|r|r|r|r|r|r|r|}
\hline & $\mathbf{N P V} \mathbf{( \$ \mathbf { m } )}$ & $\mathbf{2 0 0 8}$ & $\mathbf{2 0 0 9}$ & $\mathbf{2 0 1 0}$ & $\mathbf{2 0 1 1}$ & $\mathbf{2 0 1 2}$ & $\mathbf{2 0 1 3}$ & $\mathbf{2 0 1 4}$ & $\mathbf{2 0 1 5 - 5 0}$ \\
\hline Initial capital expenditure & $-\$ 419.3$ & $-\$ 50$ & $-\$ 120$ & $-\$ 155.0$ & $-\$ 150.0$ & $-\$ 50.0$ & & & \\
\hline Operating costs & $-\$ 576.1$ & $-\$ 50.0$ & $-\$ 65.0$ & $-\$ 65.0$ & $-\$ 65.0$ & $-\$ 65.0$ & $-\$ 65.0$ & $-\$ 65.0$ & $-\$ 572.30$ \\
\hline Revenue & $\$ 1,289.3$ & $\$ 0.0$ & $\$ 25.0$ & $\$ 45.0$ & $\$ 90.0$ & $\$ 250.0$ & $\$ 250.0$ & $\$ 250.0$ & $\$ 1,635.0$ \\
\hline Net Cash Flow & $\$ 293.9$ & $-\$ 100.0$ & $-\$ 160.0$ & $-\$ 175.0$ & $-\$ 125.0$ & $\$ 135.0$ & $\$ 185.0$ & $\$ 185.0$ & $\$ 1,062.8$ \\
\hline Net Present Value @ 12\% & $\mathbf{\$ 2 9 3 . 9}$ & & & & & & & & \\
\hline Internal Rate of Return & $\mathbf{2 4 \%}$ & & & & & & & & \\
\hline
\end{tabular}

Despite potentially being a lucrative project the company has doubts over the long term economic viability of the resource - especially given the large upfront capital outlays - and negotiates with another mineral developer to take over the project for an upfront payment $(\$ 100 \mathrm{~m})$ and reimburse developments costs to date if a decision is taken by the producer to exit the project at any stage of the development cycle.

The binomial approach for discrete time analysis of options is used to determine the inherent value - in addition to the project net present value - derived from flexibility to exit the development at any stage. The underlying asset is the resource project NPV. The NPV is assumed to exhibit a log normal distribution so the volatility of the asset is based on the logarithm of the future cash flows. It is assumed that the annual volatility of the DCF model is 55\% including all types of risk.

Figure 2 shows the binomial lattice for the asset and the valuation and decision lattice. The underlying lattice of the asset is constructed using single year time steps over 5 years. The risk free rate for the five year period under consideration is 5\%. The underlying asset value excluding the flexibility from exit is $\$ 293.9 \mathrm{~m}$. 
Figure 2: Underlying Asset, Valuation \& Decision Lattices for Coal Development

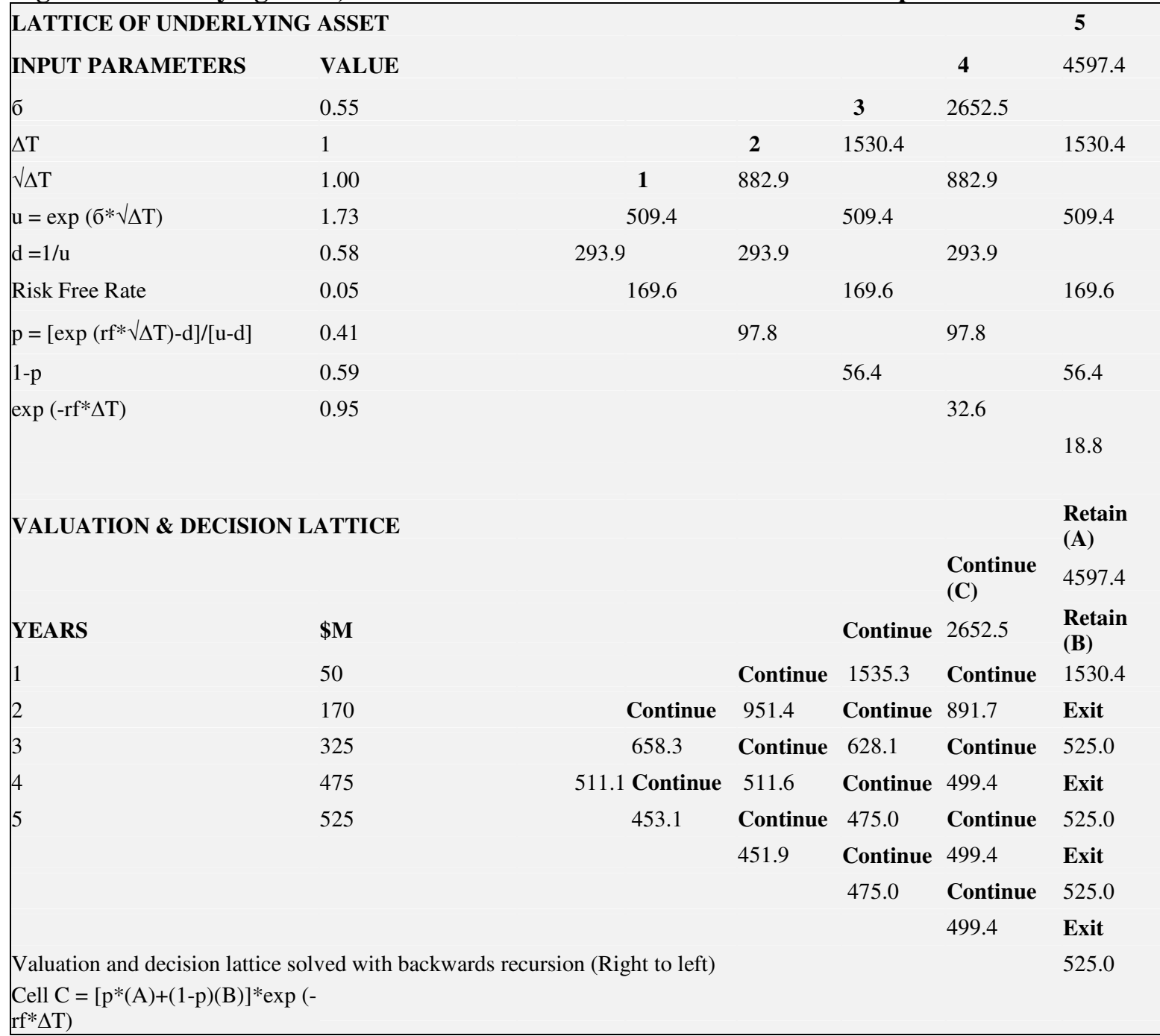

Solving the valuation and decision lattice iteratively - from right to left - shows that the flexibility of an exit option raises the value of the project NPV to $\$ 511.1 \mathrm{~m}$. On this basis the mineral resource developer would be willing to offer up to $\$ 217.2 \mathrm{~m}$ to another developer to retain the flexibility to exit the project.

The above analysis identifies the potential to underestimate expected royalties from a project with an embedded option. Under the static DCF analysis the project NPV was $\$ 293.9 \mathrm{~m}$ and the present value of sales revenues (i.e. coal exports) is $\$ 1.289 \mathrm{~m}$. Using a royalty rate of $10 \%$ the NPV of royalty collected is $\$ 128.9 \mathrm{~m}$. However the same project with an embedded option has a valuation in NPV terms of $\$ 511.1 \mathrm{~m}$.

To the extent that the option value represents increased coal export revenues, $10 \%$ of this amount would reflect the option value of government revenues from project royalty payments. If the project NPV of $\$ 511.1 \mathrm{~m}$ was due to higher coal prices - project revenue (in NPV terms) would increase to $\$ 1507.2 \mathrm{~m}$ - and royalty to collections to $\$ 150.7 \mathrm{~m}$. In this case, the static NPV estimate 
is likely to lead to an underestimate of future budget revenues from this project.

\section{Subsidising the Acquisition of Additional Environmental Benefits}

Strong sales of conventional automobiles are adding a significant amount of greenhouse gasses (GHGs) to the atmosphere. The Federal Government has a policy of encouraging early adoption of hybrid automotive technology. The potential long term economic benefits of reduced greenhouse gas emissions from adopting hybrid automobile technology are significant as there were $11.5 \mathrm{~m}$ registered motor vehicles in Australia (ABS 9309) in March 2007. If emissions were reduced by 1 tonne per year for each registered motor vehicle with an assumed \$50/tonne price for CO2-e, this could generate a gross benefit to the Australian economy of $\$ 575 \mathrm{~m}$ annually.

Recent advice from the government's greenhouse advisors suggests that a production subsidy on automobiles might increase the amount of GHGs saved. In effect the government is purchasing an environmental service - an increased reduction in GHGs. Given a tight budget constraint, the government only has $\$ 35 \mathrm{~m}$ available to achieve these reductions. The government's advisors posit there are two possible GHG reduction scenarios that might arise if this subsidy is spent on the automotive industry based either on a low $(\mathrm{L})$ vehicle uptake rate, which has a $35 \%$ chance of occurring or a high $(\mathrm{H})$ vehicle uptake rate which has a $65 \%$ chance of occurring. However, detailed results are unlikely to be known for another 12 months.

It is possible to construct an expected NPV that incorporates the net cash flows associated with a high vehicle uptake rate $(\mathrm{P}(\mathrm{H})=65 \%)$ and a low vehicle uptake rate $(\mathrm{P}(\mathrm{L})=35 \%)$. This is shown in Table 5. First, though, note that the NPV(L) is $-\$ 21.1 \mathrm{~m}$, which poses a serious risk to government in terms of achieving a successful outcome, while the NPV $(\mathrm{H})$ is $+\$ 11.2 \mathrm{~m}$.

The expected NPV analysis that combines the NPVs based on low and high uptake rates produces a result of $-\$ 9.8 \mathrm{~m}$. On this basis, government consideration of support would be ruled out. However, the expected NPV analysis critically assumes that no new information is obtained over the period of analysis (2008-2018).

Suppose that additional research becomes available in 2009 that confirms either the high or low scenario. That information has a value today.

Table 5 sets out a static discounted cash flow analysis and compares it to an option valuation. 
Table 5: Hybrid Car Subsidy, Static DCF and Option Valuation (\$m)

\begin{tabular}{|c|c|c|c|c|c|c|c|c|c|c|c|c|}
\hline \begin{tabular}{|l|} 
Hybrid Car \\
Technology
\end{tabular} & & 2008 & 2009 & 2010 & 2011 & 2012 & 2013 & 2014 & 2015 & 2016 & 2017 & 2018 \\
\hline Subsidy & $\$ \mathrm{~m}$ & -35 & & & & & & & & & & \\
\hline \multicolumn{13}{|l|}{ Uptake Rate } \\
\hline High & '000s vehicles & & 25 & 50 & 75 & 100 & 125 & 150 & 175 & 200 & 225 & 250 \\
\hline Low & ‘000s vehicles & & 10 & 20 & 30 & 40 & 50 & 50 & 50 & 50 & 50 & 50 \\
\hline Quantity saved/vehicle & CO2-e tonnes & & 1 & 1 & 1 & 1 & 1 & 1 & 1 & 1 & 1 & 1 \\
\hline High & CO2-e '000t & & 25 & 50 & 75 & 100 & 125 & 150 & 175 & 200 & 225 & 250 \\
\hline Low & CO2-e '000t & & 10 & 20 & 30 & 40 & 50 & 50 & 50 & 50 & 50 & 50 \\
\hline CO2-e Price & $\$ / \mathrm{CO} 2-\mathrm{e}$ & & 50 & 50 & 50 & 50 & 50 & 50 & 50 & 50 & 50 & 50 \\
\hline \multicolumn{13}{|l|}{ Value of CO2-e Saved } \\
\hline High & $\$ \mathbf{m}$ & & 1.25 & 2.5 & 3.75 & 5 & 6.25 & 7.5 & 8.75 & 10 & 11.25 & 12.5 \\
\hline Low & & & 0.5 & 1 & 1.5 & 2 & 2.5 & 2.5 & 2.5 & 2.5 & 2.5 & 2.5 \\
\hline \multicolumn{13}{|l|}{ Net Benefit Flow } \\
\hline High & & -35.0 & 1.3 & 2.5 & 3.8 & 5.0 & 6.3 & 7.5 & 8.8 & 10.0 & 11.3 & 12.5 \\
\hline Low & & -35.0 & 0.5 & 1.0 & 1.5 & 2.0 & 2.5 & 2.5 & 2.5 & 2.5 & 2.5 & 2.5 \\
\hline \multirow[t]{2}{*}{ Discount Rate } & $6 \%$ & & & & & & & & & & & \\
\hline & NPV & IRR & & & & & & & & & & \\
\hline High & 11.2 & $11 \%$ & & & & & & & & & & \\
\hline Low & -21.1 & $-8 \%$ & & & & & & & & & & \\
\hline \multicolumn{13}{|l|}{$\begin{array}{l}\text { Expected NPV } \\
\text { Analysis }\end{array}$} \\
\hline Expected Value High & $35 \%$ & -12.3 & 0.4 & 0.9 & 1.3 & 1.8 & 2.2 & 2.6 & 3.1 & 3.5 & 3.9 & 4.4 \\
\hline Expected Value Low & $65 \%$ & -22.8 & 0.3 & 0.7 & 1.0 & 1.3 & 1.6 & 1.6 & 1.6 & 1.6 & 1.6 & 1.6 \\
\hline Expected Value & & -35.0 & 0.8 & 1.5 & 2.3 & 3.1 & 3.8 & 4.3 & 4.7 & 5.1 & 5.6 & 6.0 \\
\hline Expected NPV & -9.8 & & & & & & & & & & & \\
\hline & & & & & & & & & & & & \\
\hline \multicolumn{13}{|l|}{ Options Analysis } \\
\hline \multicolumn{13}{|c|}{ Option Value $=$ Probability $($ High $) \times$ Max $($ High, 0$)+$ Probability $($ Low $) \times$ Max $($ Low, 0$)$} \\
\hline \multicolumn{3}{|l|}{ Probability Low Scenario } & $65 \%$ & & & & & & & & & \\
\hline \multicolumn{2}{|l|}{$\begin{array}{l}\text { Probability High } \\
\text { Scenario }\end{array}$} & & $35 \%$ & & & & & & & & & \\
\hline \multicolumn{2}{|l|}{ Max (High , 0) } & & 11.20 & & & & & & & & & \\
\hline \multicolumn{2}{|l|}{ Max $($ Low , 0) } & & 0.0 & & & & & & & & & \\
\hline OPTION & & & 7.28 & & & & & & & & & \\
\hline
\end{tabular}

The options analysis shows that achieving a high scenario has an NPV of $+\$ 7.28 \mathrm{~m}$ today.

Consequently, on the basis of achieving a future uncertain benefit, Government could actually look at providing a subsidy today to access future benefits from the high scenario. 


\section{VIII.Standard Treasury Approaches to Project Valuation}

Standard approaches to project evaluation by Australian governments generally do not refer to real options. Standard Treasury approaches to project valuation were reviewed:

- In Queensland, for example the State's main cost benefit analysis guide (Queensland Treasury (2006)) and the main environmental evaluation guide (Environmental Protection Agency (2003)) are silent in relation to real options.

- While the UK Treasury provides a definition in its Green Book (HM Treasury (2003), p104), it is silent on techniques for government practitioners.

- In New South Wales (NSW), the Government Guidelines for Economic Appraisal (2007) do not cover the application of real options techniques in the economic appraisal of projects. In concentrates on the standard approaches to project evaluation including cost benefit analysis, cost effective analysis, multi-objective analysis and economic impact analysis.

- The Victorian Department of Treasury and Finance Investment Evaluation and Policy Guidelines (1996) recommends financial analysis, sensitivity analysis, cost-effectiveness analysis, socio-economic impact analysis and distributional impacts analysis to evaluate a project. No reference is made to use of real options as part of appraising projects.

- The Western Australian Department of Treasury and Finance Project Evaluation Guidelines (2005) provide Government agencies with a technical and procedural framework for the evaluation of new and existing projects. These guidelines cover financial evaluation, economic evaluation and social impact analysis. Again, there is no discussion on the role of real options in evaluating a proposal from the public perspective.

The public sections of the websites for the remaining Australian State and Territory governments did not contain any information on the project evaluation process.

Overall, it is appears that public policy analysts in Australia are rarely directed to use real options techniques to evaluate the financial and economic merit of project proposals. Typical public sector economic evaluations tend to look at where projects are more likely to be preferred on a standard discounted cash flow/net present value basis. The following table is typical of the high level decision processes used.

Table 6: Typical Economic/Financial Decision Process

\begin{tabular}{|c|c|c|}
\hline & $\begin{array}{c}\text { Positive Financial Net Present } \\
\text { Value }\end{array}$ & Negative Financial Net Present Value \\
\hline Positive Economic Externalities & Accept proposal & $\begin{array}{l}\text { Accept if negative financial net present } \\
\text { value can be offset at a cost less than } \\
\text { the estimated positive externalities }\end{array}$ \\
\hline Negative Economic Externalities & $\begin{array}{l}\text { Accept if cost of addressing negative } \\
\text { externalities can be offset by positive } \\
\text { net present value }\end{array}$ & Reject Proposal \\
\hline
\end{tabular}

However, there are a range of circumstances under which a real options analysis may be warranted instead of a traditional NPV analysis. One set of circumstances looks at managerial flexibility and 
the likelihood of receiving new information. As Table 1 suggests, there is likely to be a high option value where there is a high likelihood of receiving new information and there is a high degree of management flexibility to be able to respond to that additional information.

Consequently, a revised decision process might be required, like one outlined in Table 7.

Table 7: Suggested Revised Economic/Financial Decision Process

\begin{tabular}{|l|c|c|}
\hline Positive Economic Externalities & $\begin{array}{c}\text { Positive Financial Net Present } \\
\text { Value }\end{array}$ & Negative Financial Net Present Value \\
\hline Negative Economic Externalities & $\begin{array}{c}\text { Accept proposal } \\
\text { Accept if cost of addressing negative } \\
\text { net present value AND any option } \\
\text { value embedded in the externalities }\end{array}$ & $\begin{array}{c}\text { Accept if negative financial net present } \\
\text { value can be offset at a cost less than } \\
\text { the estimated positive externalities } \\
\text { AND any option value embedded in the } \\
\text { project }\end{array}$ \\
\hline $\begin{array}{c}\text { significant posal UNLES the real option values } \\
\text { either for the proponent or for the } \\
\text { community (expressed as externalities) }\end{array}$ \\
\hline
\end{tabular}

This has significant implications for the direction of evidence-based public policy. To the extent that there is a significant real option value associated with a project or proposed government program, there is a risk that the direction of this option value may either support or cut across the preliminary net present value analysis that is undertaken.

\section{Conclusions}

There are a range of circumstances under which a real options analysis may be warranted instead of a traditional NPV analysis. One set of circumstances looks at managerial flexibility and the likelihood of receiving new information. There is likely to be a high option value where there is a high likelihood of receiving new information and there is a high degree of management flexibility to be able to respond to that additional information.

The above examples have shown that from a Government decision making perspective, projects that contain embedded option values for private proponents, if not valued by Government, may lead Government to conclude that financial assistance is warranted for the a project when it is not actually needed. A static DCF analysis is likely to underestimate the value of these projects is embedded options are not incorporated into the project valuation.

While the above examples have focused on resource and industry projects that are predominantly private sector projects, broader application of the real options analysis technique could see it used more in the social infrastructure and significant social project contexts - particularly in terms of siting new health services or education facilities. Also, as an owner of significant assets with the economy, government has a stewardship role. This could be enhanced by a more considered application of real options analysis in terms of maintenance and renewals planning as part of a broader strategic asset management approach. Further research in these areas is considered warranted. 


\section{References}

Australian Bureau of Statistics Motor Vehicle Census (2007) ABS 9309.0

Bailey,W. Bhandari, A. Faiz,S. Srinavasan, S. and Weeds, H. (2003) 'Unlocking the Value of Real Options' Oilfield Review Winter 2003, Vol. 15, No. 4, pp. 4-19

Bellalah, M. (2002) 'Valuation of commodity assets and the option to invest in the presence of stochastic prices and incomplete information', Conference Paper, 6th Annual Real Options Conference, Paphos, Cyprus, 4-6 July 2002

Boyle, G. and Irwin, T. (2004) 'A Primer on Real Options', New Zealand Institute for the Study of Competition and Regulation, 11 May 2004

Brandao, L.E.T. and Saraiva, E.C.G. (2007) 'Valuing Government Guarantees in Toll Road Projects', realoptions.org

Brennan, Michael and Eduardo Schwartz (1985) "Evaluating Natural Resource Investments" Journal of Business 58: 135-157.

Copeland, T. Koller, T. and Murrin, J. (2000) Valuation: Measuring and Managing the Value of Companies, Third Edition (University Edition), McKinsey \& Company, Inc., John Wiley \& Sons, Inc.

EPA (2003) Environmental Economic Evaluation: An Introductory Guide for Policymakers and Practitioners, Queensland Environmental Protection Agency

HM Treasury (2003) The Green Book: Appraisal and Evaluation in Central Government

Kruger, N.A. and Svensson, M. (2007) 'The Impact of Real Options on the Willingness to Pay for Mortality Risk Reductions' Working Paper No.9, 2007, Working Paper Series, Economics Department, Orebro University, Sweden

Leslie, K.J. and Michaels, M.P. (1997) 'The Real Power of Options', The McKinsey Quarterly, 1997, No.3, pp97 - $108<$

McCormack, J. Stern Stewart \& Co. and Sick, G. (2001) 'Valuing PUD Reserves; A Practical Application of Real Option Techniques', Bank of America, Journal of Applied Corporate Finance

New South Wales Treasury (2007) NSW Guidelines for Economic Appraisal, Policy and Guidelines Papers, Office of Financial Management

Osborne, C. (2008) 'Economist's Corner - Real Options Should Be Part of Our Thinking', The Way Ahead, Vol.4, No.1, Society of Petroleum Engineers , p24

Queensland Treasury (2006) Cost Benefit Analysis Guidelines - Achieving Value for Money in Public Infrastructure Service Delivery, Project Assurance Framework, Supplementary Guidance Material

Smit, H.T.J. and Trigeorgis, L. (2003) 'Real Options: Examples and Principles of Valuation and 
Strategy', School of Economics, Erasmus University Rotterdam

Schwartz, E.S. and Trigeorgis. L. (2004) Real Options and Investment Uncertainty Classical Readings and Recent Contributions, paperback edition, First MIT Press

Victorian Department of Treasury and Finance (1996) Investment Evaluation Policy and Guidelines

Western Australian Department of Treasury and Finance (2005) Project Evaluation Guidelines 